\title{
The International Monetary Fund (IMF) And World Bank: An Assessment Of The Role Of Africa's Integration Into Global Economic System
}

\author{
Tion, Patrick Aondoakaa \\ Department Of Political Science Federal University, Wukari, Taraba State
}

\begin{abstract}
The politics of globalization is the process of greater interdependence among countries and their citizens. The process is a multifaceted and complex one. Globalization seem to have evolved as an avenue to help the less developed countries to grow but it has rather worsened the developing nations growth quest. Globalization has brought to fore two prominent institutions (the World Bank and International Monetary Fund) which are supposedly to be rendering assistance to developing nations to be self sustainable but it have rather turnout to be means through which developing nations are economically subjugated. Using the Marxist capitalist theory, the work is aimed at taking a critical study of the position of African nations in the global economic system vis a vis the developing nations, specifically considering the roles of the International Monetary Fund (IMF) and the World Bank. The work in its conclusion posits that globalization is a neocolonial structure aimed at tiring the developing nations permanently to poverty while developed nations make mines of them.
\end{abstract}

Key Words: System, Economic System, Globalization, Integration, Role and Assessment

\section{Introduction}

Globalization is the process of greater interdependence among countries and their citizens. It is complex and multifaceted. Most of the problems pointed out by the critics of globalization are real. Some of the problems are economic related while others are non-economic, but none the less important aspect of life. While some of the problems stem from the process of global integration, others do not. As far as the economics is concerned, the big challenge is poverty, and the surest route to sustained poverty reduction is economic growth. Growth requires good economic policies; the evidence strongly supports the conclusion that growth requires a policy framework that prominently includes an orientation towards integration into the global economy. This places obligation on three groups; those who are most responsible for the operation of the internationals economy, primarily the governments of developed countries; those who determine the intellectual climate, which includes the academia, also government and non-governmental organizations and individuals; and the governments of the developing countries who bear the major responsibility for economic policy in their countries.

The World Bank and the International Monetary Fund (IMF) are the two most powerful institutions in global trade and finance (Halifax, 1997). Since 1980, the United States government which dominates both bodies has used them to economically subjugate the developing world. The World Bank and the IMF have forced third world countries to open their economies to Western penetration and increase exports of primary goods to wealthy nations. These steps amongst others have multiplied profits for Western multinational corporations while subjugating Third World countries to horrendous levels of poverty, unemployment malnutrition, illiteracy and economic decline and the worst affected region has been Africa. For two decades, the World Bank and IMF have forced developing countries to create conditions that benefit the Western Corporations and governments. These conditions are known as Structural Adjustment Programmes (SAPs). SAPs require governments to; cut public spending,(including eliminating subsidies for food items, medical care and education); raise interest rates, thus reducing access to credit; privatize state enterprises; increase exports; and reduce barriers to trade and foreign investment such as tariffs and import duties. These measures are supposed to generate export-led growth that will attract foreign direct investment and can be used to reduce debt and poverty (Naiman, 1999).

According to a three-year, multi-country(including three African countries) study released in April 2002 by the Structural Adjustment Participatory Review International Network which was prepaid in collaboration with the World Bank, national governments and civil society, SAPs have expanding poverty, inequality and insecurity around the world. They have eaten into the heart of economies and the social fabrics, increasing tensions among different social strata, fueling extremist movements and delegitimizing demotic 
political systems. Their effects, particularly on the poor are so profound and pervasive that no amount of targeted social investments can begin to address the social crises that they have engendered (Saprin, 2002).

SAPRIN,(2002)explained this damning indictment by identifying four ways in which reforms under SAP have impoverished people and increased economic inequality. Firstly, trade and financial sector reforms have destroyed domestic manufacturing leading to massive unemployment of workers and small scale producers. Secondly, agriculture, trade and mining reforms have reduced the incomes of small scale farmers and poor rural communities as well as their food security. Thirdly, labour market flexibility measures and privatizations have caused mass layoffs of workers and resulted in lower wages, less secured, fewer benefits and "an erosion of worker's rights and bargaining power". Privatization of major national assets and essential services has allowed multinational corporations to remove resources and profits remove resources from countries as well as increase rates for water and electricity which has hit the poor the hardest. Fourthly, the cutting of health and education spending under SAP and introduction of user fees for these services, when combined with higher utility rates, has resulted in "a severe increase in the number of the poor as well as deepening poverty".

This paper therefore assesses the role of IMF and World Bank on the integration of Africa into the global Economic System. The paper covers an overview of the World Bank, the IMF and SAP: effects of conditions imposed by the World Bank and the IMF's SAP on Africa: case study-Ghana: Africa's road map development.

\section{An Overview Of The World Bank, The Imf And Structural Adjustment Progamme}

The World Bank or the international Bank for Reconstruction and Development (IBRD) and the International Monetary Fund (IMF) were created in 1944 by leaders of 44 nations at Bretton Woods conference. The World Bank was responsible for financing long term productive investment in member countries while the IMF was to provide loans to overcome short-term balance of payment deficits. Western leaders feared an unregulated world market would mean a return to depression, poverty and another world war (Hayter, 1985). At Bretton Woods (located in New Hamphire, US), "the decisive factor was the reality of American power". With much of Europe destroyed by the Second World War, the US was economically the world's most powerful country; thus a US vision prevailed at the conference and the World Bank and the IMF were created along US lines. Unlike the UN, also founded at the time, the World Bank and the IMF were controlled by one dollar onevote rather than one country one-vote. Washington alone has veto powers over decisions about the mandates and structure of the organizations. This is because the US' is $17.16 \%$ in the IMF and $16.41 \%$ in the World Bank and both organizations changes to the Articles of agreement required $85 \%$ of the votes. Japan holds the next highest voting shares with $6.27 \%$ and $7.87 \%$ respectively. The US also has the privilege of appointing the President of the World Bank and is the only country entitled to permanent place among the Bank's executive directors (Feinberg, 1986).

The World Bank group is made up of five organizations: The IBRD which provides loans and development assistance to middle-income and credit worthy poor countries; International Development Association (IDA), the Bank's concessional lending arm, focused on the poorest countries to which it provides near zero-interest loans. International Finance Corporation (IFC) which finances private sector investments in developing world and provides technical assistance to governments and businesses. Multilateral Investment Guarantee Agency (MIGA) which encourages foreign investment in developing countries by providing guarantees to foreign investors against loss caused by non-commercial risk. Lastly, the International centre for Settlement of Investment Disputes (ICSID) provides international facilities for arbitration of investment disputes (Halifax, 1997). As constituted, the World Bank is supposed to be both a bank and development agency focused on poverty alleviation whereas the IMF is only a financial institution.

The debt crisis in the 1980s gave Washington the opportunity to blast open and fully subordinate Third World economies through World Bank-IMF structural adjustment programmes (SAP) Bello,2001). Starting in 1980, developing countries were unable to pay back loans taken from Western Commercial Banks which had gone on a huge lending binge to Third World governments during the mid to late 1970s when rising oil prices had filled up their coffers with petro-dollars (George, 1988). The World Bank's and IMF imposed SAPs on developing countries that needed to borrow money to service their debts. The World Bank's SAP, first instituted in 1980, enforced privatization of industries (including necessities such as healthcare and water), cuts in government spending and imposition of user fees, liberalizing of capital markets (which leads to unstable trading in currencies) market based pricing (which tends to raise the cost of basic goods) higher interest rates and trade liberalization. SAP evolved to cover more areas of domestic policy, not only fiscal, monetary and trade policy but also labour laws, health care, environment regulations, civil service requirements, energy policy and government procurement (Halifax,1997).

With the imposition of its own SAP in 1986, the IMF became "one of the most influential institutions in the world." Its 2,500 staff dictates the economic conditions of life to over 1.4billion people in 75 developing 
countries. As one observer put it, "Never in history has an international agency exercised such authority." Until the 1980s, IMF involvement with Third World countries had been short-term and its impact minimal but after the debt crisis it took on a greatly expanded role in imposing austerity conditions on countries in financial difficulties (Toronto Star, 1997). The fund became gendarme for Western commercial Banks ensuring that they would get repaid and helping them consolidate their power over poor nations. Borrowing countries knew that they not get further loans from other sources without the IMF seal of approval. One other observer called the fund, "a sort of Godfather figure, it makes countries offers they can't refuse" (George, 1988) Classical IMF stabilization programme involve: a standard set of policies aimed at reducing current account deficits. These invariably include a contraction of the money supply and fiscal austerity measures aimed at reducing "excessive demand" in the domestic economy; demands for strict anti-inflationary monetary policy, privatization of public enterprises, trade liberalization and dismantling of foreign exchange controls; more flexible labour markets (in other words, a lowering of labour standards) and reducing the size of the public sector. This has meant cutbacks to education, health care and the elimination of subsidies and marketing boards for agricultural products as well as the privatization of such basic services as portable water, health care and education (Halifax, 1997).

During the period 1980-93, 70 developing countries were subjected to 566, stabilization and structural adjustment programmes with disastrous consequences; the 1980s became known as the "lost decade." Between 1984 and 1990, Third World countries under SAP transferred \$178 billion to Western commercial Banks. So enormous was the capital drain from the south that Morris Miller, a Canadian former World Bank Director remarked: "Not since the conquistador's plundered Latin America has never in the world experienced such a flow in the direction we see today (Bello, 1993). By severely restricting government spending in favor of debt repayment, the loan terms of the Bank and the IMF eviscerated the third world state leaving in its wake spiraling poverty and hunger fueled by slashed food subsidies decimated health and education sectors. Growth stagnated and debt doubled to over $\$ 1.5$ trillion by the end of the 1980 s, doubling again to $\$ 3$ trillion by the end of the 1990s (Halifax, 1997). As U.N. Secretary General Javier Perez de Cuellar noted in 1991: "The various plans of structural adjustment, which undermine the middle classes; impoverish wage earners; close doors that had begun to open to the basic rights of education, food, housing, medical care; and also disastrously affect employment, often plunged societies, especially young people, into despair (Raymond, 1991).

After 15 years of following World Bank and IMF-imposed policies, Latin America, by the late 1990s, was going through "its worst period of social and economic deprivation in half a century." By 1997, nearly half of the region's 460 million people had become poor, an increase of 60 million in ten years. Populations, overall, were worse off than they were in 1980. The United Nations Economic Commission for Latin America and the Caribbean (ECLAC) stated in 1996: "the levels of poverty are still considerably higher than those observed in 1980 while income distribution seems to have worsened in virtually all cases" (Schrieberg, 1997). SAP imposed on Peru by the World Bank and IMF pushed four million people into extreme poverty, almost halved real wages, and cut those with "adequate employment" to 15 percent of the workforce. Consequently, there was a forced migration of impoverished peasants and urban unemployed into cocoa growing (for drug traffickers) as an alternative to salvation. In 1991, in exchange for \$100 million from the United States, Peru put in place the IMF structural adjustment clause opening its markets to US corn. As a result, by 1995, corn cultivation had fallen tenfold and cocoa production had grown by percent. Under these conditions, corruption flourished; indeed almost an entire economy was criminalization. Increased cocoa production meant more cocaine trafficking which led to deepening official corruption in Peru as the amount of money in the hands of drug lords increased (Isma, 1998).

An IMF-sponsored stabilization package implemented in Peru in 1990 had the following consequences: "From one day to the next, fuel prices increased 31 times by $2,968 \%$. The price of bread increased 12 times by $1,150 \%$. The prices of most basic staple foods increased by six times, $446 \%$ in a single month yet wages had already been compressed by $80 \%$ in the period prior to adoption of these measures in August 1990" (Raymond, 1991) IMF SAP were imposed on Mexico in 1982; in the following decade infant deaths due to tripled, the minimum wage fell by $60 \%$ and the percentage of the population living in poverty rose from less than half to more than two thirds. More recently, World Bank-IMF SAP played a major role in causing the collapse of the Argentine economy in December 2001; these SAP also fuelled the Asian financial crisis of 1997 (Sanders, 1998).

\section{Effects Of The Conditions Imposed By The World Bank And Imf's Sap On Africa}

According to UN Economic Commission for Africa (ECA) "the major thrust of economic policy making on the continent has been informed for the last decade or so by the core policy content of adjustment programmes (of the type supported by the IMF and World Bank)." The New York Times called the World Bank and IMF, the overlords of Africa." Beginning from 1980, SAP has been imposed on 36 of Sub-Saharan Africa's 47 countries. As a result of SAP, Africa is more integrated into the global economy than ever. SAP's emphasis on export-led growth has significantly expanded African trade levels. From 1989 to 1999, Sub-Saharan Africa's 
trade as a percentage of GDP (a key indicator of globalization) increased from $78.1 \%$ to $95.6 \%$, in dollar terms, trade grew from $\$ 175$ billion in 1990 to $\$ 187$ billion in 1999; for the same period, foreign direct investment jumped from $\$ 923$ million to $\$ 7.9$ billion in 1999 and portfolio investment (for equity) shot up from $\$ 2$ million to $\$ 3.9$ billion; debt service increased from $12.9 \%$ to $13.9 \%$ of exports. Only official aid to Sub-Saharan Africa fell from \$19.4 billion in 1994 to $\$ 12.5$ billion in 1999 (World Bank, 2001). However, contrary to World Bank dogma, export expansion and rising foreign investment in Africa, have not increased growth nor reduced debt and poverty level, as seen below, they have had exactly the opposite effect. Most African exports are raw materials and non-oil commodity prices have dropped by 35\% on average since 1997 (World Bank, 2002). Foreign investment contributes little to African economies, due to incentives given to the companies such as tax holidays and profit repatriation allowances. After considerable social and economic progress during 1960-1980, the following 20 years of structural adjustment have devastated the continent. Some of the impacts of the adjustment are stated below.

Slower Growth: during 1960-1980, Sub-Saharan Africa's GDP per capita grew by 36\%; in the period 19802000, it actually fell by $15 \%$. As the center for Economic and Policy Research puts it, "These are enormous differences, by any standard of comparison and represents, the loss to an entire generation, of hundreds of millions of people, of any chance of improving its living standards" (Weisbrot, 2002)

Increased Poverty: According to the World Bank (2003), over 350 million people (more than half of Africa's population of 682 million) lived below the poverty line of U.S $\$ 1$ a day, a $75 \%$ increase over the 200 million; the figure for 1994.

Lower Incomes: Africa's estimated per capita income in 1990 was at the level it had been in 1960. Per capita incomes for most Sub-Saharan countries fell by $25 \%$ during the 1980s and for 18 countries these incomes were lower 1999 than in 1975. In 1960, Sub-Saharan Africa's per capita income was about 1/9 of that in high-income OECD countries; by 1998 , it had deteriorated dramatically to about $1 / 18$.

Low Human Development Indicators: According to the UN Development Programme (UNDP), 80\% of low human development countries, those with low income, low literacy, low life expectancy and high population growth rates, are in Africa (UN, 2001). Average life expectancy for Sub-Saharan Africa is only 47 years (the lowest in the word), a drop of 15 years since 1980. Forty per cent of the population suffers from malnutrition that causes low birth weight among infants and stunts growth in children. In 2000,30\% of children under five were underweight in Sub-Saharan Africa; thirty-seven percent of such children were under height (UNDP, 2002).

Increased Debt Burdens: under SAP, Africa's external debt has increased by more than $500 \%$ since 1980 to $\$ 333$ billion today. SAP has transferred \$229 billion in debt payments from the Sub-Saharan Africa to the West since 1980. This is four times the region's 1980 debt. In the past decade alone, African countries have paid their debt three times over yet they are three times as indebted as ten years ago. Of Sub-Saharan Africa's 44 countries, 33 are designated heavily indebted poor countries by the World Bank. Africa, the world's poorest region, pays the richest countries $\$ 15$ billion every year in debt servicing. This is more than the continent gets in aid, new loans or investment. Jubilee (2000) U.K warns that "Foreign indebtedness now poses a fatal impediment to Africa's development." In 1997, the UNDP stated that in the absence of debt payments, severely indebted African countries could have saved the lives of 21 million people and given 90 million girls and women access to basic education by the year 2000. The all African conference of churches has called the debt "a new form of slavery, as vicious as the slave trade. According to Africa Action, a Washington D.C based advocacy group, "the U.S appears unwilling to support debt cancellation for Africa because the U.S actually gains a great deal from Africa's economic enslavement. The U.S and other rich countries of the world, as well as the World Bank and IMF, use Africa's debt as leverage to manipulate the continent's economic fate to serve their interest" (Colgan, 2000).

Decreased in Health Care and Increased in Disease: Africa spends four times more on debt interest payment than on health care. This combined with cutbacks in social expenditure caused health care spending in the 42 poorest African countries to fall by 50\% during the 1980s. As a result, health care systems have collapsed across the continent creating near catastrophic conditions. More than 200 million Africans have no access to health services as hundreds of clinics, hospitals and medical facilities have been closed; those remaining open were generally left understaffed and without essential medical supplies. This has left disease to rage unchecked leading most alarmingly to an AIDS pandemic. With about $12 \%$ of the world's population, Africa accounts for $80 \%$ of the world's deaths due to malaria. More than 17 million Africans have died of HIV/AIDS and an estimated 28 million of the 40 million people living with the disease worldwide are in Sub-Saharan Africa. More than 12 million African orphans have lost their mothers or both parents to AIDS. Presently, malaria is killing 900,000 people annually across the continent and according to the World Health Organization (WHO) 3.3 million Africans were to have Tuberculosis in the year 2005 (Colgan,2000). 
Lack of Clean Drinking Water: More than half of Africa's population is without safe drinking water and twothird do not have access to adequate sanitation. Water privatization schemes in Ghana and South Africa are further depriving poor people of access to potable water.

Decrease in Education Levels: ten African governments spent more on debt repayments than on primary education and health care combined in 2002. Forty percent of African children are out of school and Africa is the only region where this number is rising. Between 1986 and 1996, per capita education spending fell by $0.7 \%$ a year on average. The adult literacy rate in sub-Saharan Africa is well below the developing country average of 73\%. More than 140 million young Africans are illiterate. Given the horrifying social impact of SAP all over Africa, it is not surprising that Emily Sikazwe, director of the Zambian anti-poverty group "Women for Change," asked: "What would they (the World Bank and the IMF) say, if we took them to the World Court in The Hague and accused them of genocide?" (Lynas, 2000)

\section{A Study Of Ghana}

Structural Adjustment has had its impact on Ghana where it was first implemented in 1983 under a military government. Seen as a "star pupil" by the World Bank and the IMF, Ghana privatized more than 130 state enterprises, including the mining sector (its main source of revenue), removed tariff barriers and exchange regulations and ended subsidies for health and education (Kofi, 1997). As a result, 20\% of Ghanaians are unemployed and the cost of food and services has gone beyond the reach of the poor. GDP per capita was lower in 1998 (\$390) than it was in 1975 (\$411); 78.4\% Ghanaians live on $\$ 1$ a day and $40 \%$ live below the poverty line; $75 \%$ have no access to health services and $68 \%$ none to sanitation. As with Zimbabwe, the World Bank's emphasis on export expansion to reduce debt has only increased Ghana's external debt from $\$ 1.4$ billion in 1980 to $\$ 7$ billion in 1999. This has made Ghana subject to the World Bank's Highly Indebted Poor Countries (HIPC) initiative.

In agriculture, Ghana used to be self sufficient in rice but the World Bank insisted that subsidies had to stop and markets had to open. As a result, the Katanga valley, once Ghana's rice bowl now lays fallow and U.S. rice has become the staple for the Ghanaians (Jubilee, 2000). Why is this so? It is so because United States' rice is subsidized and therefore cheaper than that grown in Ghana. The introduction of user fees for health care in 1985 combined with falling wages and increasing poverty has reduced out-patient attendance at hospitals by a third especially in rural areas. As one observer put it, "Patients pay for everything, for surgery, drugs, blood, scalpel, even then, cotton wool." This is what the World Bank calls "full cost recovery" and it has priced the poor out of hospital care. Those who use services and cannot afford to pay such as Betty Krampa, who gave birth in Tarkwa General Hospital, are kept prisoner until the fees are collected (SAPRIN,200). User fees in education have raised the primary school drop-out rate to $40 \%$. Sharp fee rises at the secondary and again at the college level have led to only one in 400 Ghanaians being enrolled at post secondary institutions. As the SAPRIN study notes, "User fees have led to increasing inequalities both between and within communities as the poor are left behind"(SAPRIN,2000)

Ghana's SAP experience has been particularly damaging in the areas of mining sector reform and privatization of water. Gold mining is Ghana's main source of revenue and foreign exchange. In 1998, gold exports totaled $\$ 793$ million which was $46 \%$ of gross foreign exchange earnings (Mining watch Canada, 2001). Under the SAP, beginning in 1986, there has been massive privatization of the mining sector accompanied by generous incentives for companies which include the repatriation of up to $95 \%$ of their profits into foreign accounts and the ending of income tax and duties. Environmental regulation has been minimized. Such a favourable investment climate has attracted multinational corporations and boosted production. Seventy to eighty-five per cent of the large-scale mining industry is now foreign owned (the government owned $55 \%$ of all mining companies before 1986) with more than half the 200 active concessions belonging at least in part to Canadian companies. Ghana is now Africa's second largest producer of gold after South Africa and gold constitutes more than $90 \%$ of total value of minerals output. Gold production reached a record high in 1995 and has since gone up by a further 45\% (Mining Watch Canada, 2001).

All this has, however, not benefited the Ghanaian economy and people. As the SAPRIN study states: "Liberalization, deregulation and privatization of the mining sector have enabled transnational corporations to remove resources and profits from poor countries while failing to generate sustainable economic growth that is of net benefit to national or local economies." Due to tax breaks and incentives given to foreign companies, mining's net foreign exchange contribution to Ghana's economy has been minimal. The sectors contribution to government revenue has also been small at $14.4 \%$ in 1995 . Mining's ability to generate employment is also limited given that all operations are of the surface-mining kind which is capital intensive. The sector employs about 20,000 people but privatization and the decline in commodity prices has led to cost-cutting which has meant massive layoffs; many mines substantially reduced their labour force particularly during 1997-2000. At the same time mining has caused high unemployment in surrounding communities by taking away large tracts of 
land from farmers and not providing enough jobs to make up for the number of people laid off from agriculture (SAPRIN, 1997).

The district of Tarkwa which contains half of Ghana's large mines shows the enormous social and environmental impact of the gold boom. Mining here, displaced 30,000 people between 1990-98, contaminated rivers and streams and destroyed farm and forest lands. Two-thirds of the land in Tarkwa has been sold off to multinationals with minimal compensation to local owners. The dislocation affects "every aspect of the social fabric" and has led to high levels of prostitution, a rise in the incidence of AIDS, family disorganization and unemployment as people lose their farms. The police have intervened when people refused to leave and demanded fair compensation from the company for their lost land, crops and home. In December 1999, police shot and wounded nine people during demonstrations against layoff of 1,000 workers by Goldfields (Ghana) Limited (18.9\% owned by IAMGOLD Corporation of Toronto) (Mining Watch Canada, 2001). Air and water pollution stemming from mining operations in Tarkwa have spread malaria, tuberculosis, silicosis, acute conjunctivitis and skin diseases. The mines use cyanide heap leach technology which involves spraying cyanide on ore to extract Gold. The dams used to hold the cyanide in tend to fail. In June 1996, a spill at Teberebie Goldfields sent 36 million litres of cyanide solution into the Angonaben stream, a tributary of the Bonsa River. Cocoa crops and fish ponds were destroyed and local people complained of lashes. The affected farmers sued the company for compensation in 1997 and the case, continues (Mining Watch Canada, 2001).

Not satisfied with mining's destruction of forestry, the World Bank has pushed the government to intensify commercial forestry. Timber production more than doubled between 1984 and 1987, speeding up the destruction of Ghana's already diminished forest cover, which is now 25 percent of its original size. Ghana is expected to soon become a net importer of wood from being a net exporter. The SAP has denied Ghanaians not only their most lucrative resource but also their most basic and necessary one; water. The World Bank has decreed the privatization of Ghana's water supply for the purpose of "increased cost recovery" (as with health care and education) arguing that a debt laden government should not subsidize water and sanitation( never mind that many industrialized countries do). Instead, consumers will have to cover the costs of operating, maintaining and expanding water services. This will mean higher water rates for people who have already been made amongst the poorest in the World by the World Bank's SAP. Thirty-five percent of Ghanaians lack access to safe water; poor and very poor households who have no water pipes laid to their residence make up to 50 and $70 \%$ of Accra's (Ghana's capital) population. These households buy water or get it from untreated hand-dug wells. As Rudolf Amenga-Etego of the Integrated Social Development Centre in Ghana explained: "Most people in Accra do not earn the minimum wage (5,000 cedis a day), and a significant number have no regular employment. An average price for a bucket of water which is used to be 400 cedis rose to 800 cedis following an over $100 \%$ increase in water and electricity tariffs announced on April 20, 2001. Privatization is expected to increase water tariffs even further. The current water tariff rates that the government of Ghana and the World Bank think are below the market rate are already beyond the means of most of the population. So how will the population possibly be able to absorb a so-called "open market" price in the context of privatization? As water becomes less affordable, it is highly likely that there will be a corresponding increase in diseases stemming from reduced access to clean water (Amenga-Etego, 2000).

The water privatization process in Ghana has been marred by scandal and accusations of corruption. In 2000, the government awarded the contract to Enron/Azurix, consortium of British and American companies. Enron, the biggest bankruptcy in U.S. history, is now of course a byword for fraud and corruption. The contract had to be withdrawn due to public protest in reaction to allegations that a $\$ 5$ million kickback had been paid to the minister of works and housing. The bidding was started again but remained un-transparent. Two of the corporations' bidding for water service, Lyonnaise des Eaux and Bouygues/Saur have annual sales larger than Ghana's GDP which limits government influence over them. Both these companies have been dogged by corruption scandals in France and Lesotho (Amenga-Etego,2001). Joseph Stiglitz, fomer chief Economist at the World Bank, called privatization, "briberization". He spoke of "national leaders told to sell their countries water and electricity companies, who were keen to get commissions paid into Swiss bank accounts". As he puts it, "You could see their eyes widen" at the prospect and "objections to selling of state industries were silenced".

Clearly, the World Bank's structural adjustment of Ghana is a textbook example of how to ruin a country. The ruthless denial of mineral wealth, food, medical care, education and even water has made the population destitute spectators to the plunder of Ghana by foreigners.

\section{The Way Forward- Africa's Road Map To Development Conflicts And Insecurity In Africa}

Africa is in perpetual conflicts and insecurity to lives and properties due to internal crisis that are mostly caused by competition for natural resources. These conflicts are heightened due to easy access to guns as a result of weapon proliferation across its borders. Africa is endowed with both human and natural resources but lacks capacity to deal with effects of weapons and wars, a case that could be likened to lantis (1988)'s observation that: "when governments devote founds to build up large armies and weapons of mass destructions, 
they are also choosing to divert funds from other programs like productivity and health care. Clearly citizens of the world experience these direct and indirect effects of proliferation every day"

A robust relationship exists between arms buildup and like hood of conflict, it is argued that for Africa to experience stability, peace and development, arm buildup should be discouraged, as they are expensive and diverts resources from much needed areas and most importantly, the continent lacks capacity to address conflicts that overstretch both human and capital. Hot spots like Darfur, (Sudan), Somalia, Niger Delta (Nigeria) etc are conflicts area, where collaborative effort through diplomacy and humanitarian concerns may resolve them. More importantly, harmonized efforts would provide the significant opportunity to improve investment climates as well as safeguard Africa's position as an alternative source of energy as opposed to the volatile Middle East.

\section{A Harmonized Development Approaches And Investment Initiatives}

As firm believers with shared commitments to the UN's Millennium Development Goals, security, human rights as well as sustainable economic development that reduces poverty, taking into account individual country unique characteristics, national problems and development objectives, a trilateral approach would require harmonized resources, aids technical assistance and sharing of expertise with national and regional governments, as well as non governmental agencies that would ensure that their efforts are not counterproductive. The presence of US and China in Africa, poses a challenge for Europe as a traditional colonial power in Africa, as it still holds a strong position in the economy of African countries. It has to come away from its monopolistic stand and face the brutal awakening and realization that the world of trade has changed drastically in the future it must pay a fair price for its consumption and it must do this in competition with others by joining the global drive to integrate Africa into the global economic. Therefore, the current assessment of trade between Africa and China which has promoted growth in Africa mend the presence of U.S would require a balance of power in which it is left for Africa to take advantage of these opportunities (Dieye and hanson, 2008)

Furthermore, Kotsopoulos (2007) underscores Africa's importance to the EU as an alternative source of energy and raw material. China has been strongly criticized for being less scrupulous about dealing with represent or corrupt regimes in the region and using development funds to help Chinese enterprises in Africa. The presence of the EU and the US would provide balancing equation of the economic power that is shaped by international trade negotiated agreements to favor Africa countries in tandem with the Em's strategy of a comprehensive, integrated and long-term framework for relations with Africa. It is argued that it would be to Africa's advantage to seize this opportunity to harness its development using institutions like the African Development (NEPAD)Economic community of west African States for Africa's (ECOWAS), South African Development Cooperation (SADC) and other regional organs to ensure a meaningful and fruitful relation.

Similarly, the EU supports regional strategies for growth and poverty reduction in Africa that enhance macroeconomic stability, encompasses private investments and promote economic growth through direct participation of the poor and utilization of resources to remove the effects of exogenous shocks like sharp initiatives like environmental improvement, creation of wealth, employment and business competition that reduces costs for consumers and increase revenues for individual governments is a welcome development and a preparatory ground for review of the west's past policies in Africa which have been considered unproductive. This should be aligned with the challenges presented by china in Africa based on common front and individual partner's Joint Plan of Action on Africa and UN's multilateral organs like Food Agriculture Organization (FAO) World Trade Organization (WHO and prepare the ground for global market integration.

Consequently, call for a triangular approach would enable partners to appreciate each other's strengths and weakness and to dialogue on a regular basis on those significant and complete issues relating to Africa in a serious and constructive manner as well as appreciate the peculiarities of African countries as developing economics with cultural, social and economic difference; using NEPAD's integration to African Union structure for a more proactive stance on issues of development, diversifying the economics and increasing their exports. This requires engaging in effective regional trades and cooperation. The responsibility lies with Africa to make or mar the opportunity. Analysts infer that what remains of NEAD is to demonstrate great political will and commitment that would ensure achieving Africa's development initiatives, which would yield results for individual nation. The differences in policy thrusts should not be seen as a deterrent but a catalyst for productive engagements in Africa.

Finally, this partnership is a timely one for the purpose of removing the perceived suspicion with which china and U.S view each other's presence I Africa. In a global economy, competitiveness for resources is not only positive but healthy as it leads to job creation, reduced costs for consumer goods, increased revenues for the governments and partners and in the long run it is beneficial to all. This approach would present the U.S the opportunity to address the nascent issue that Washington is afraid of china as an emerging economy and investment power through its increasing influence in Africa, Asia and the international community. On the other 
hand, this would enable China to be more proactive in her initiatives as opposed to her discreet engagements in multilateral organizations for fear that it would be wrongly perceived by the west as asserting a super power influence and for the EU this would correct the misconception that she had helped in the plundering of resources in the past and turned her back.

\section{Effective Use Of Oil Revenues, To Reduce Poverty And Hunger.}

Arising from the fact that past African oil revenues have never benefited the citizens due to poor institutionalized corruption and bad governance, overvalued currencies and poor macroeconomic policies in dealing with the "resource abundance" and "resources curse", African countries resorted to aids and borrowing. But, with all the aid and economic assistance the continent has not faired well as it's is projected that by 2030 , Africa would still be wallowing in absolute poverty. To achieve its UN's Millennium Development Goals and offer its nationals economic prosperity and pull them out of poverty it has to manage its new partnership in a strategic and responsible way and position the oil sector as engine for growth of other sectors, as well as prioritize development goals that would economically integrate it to the global economy.

The U.S. oil demands are projected to reach 28.3 million barrels pper day by 2025 , but fluctuation in oil prices production and sociopolitical crisis in the Middle East has led to speculation that its depend ace from this region posed a security risk, deterrent to good governance, spread of democratic governance and war on terrorism. The U.S needs to look towards Africa for its oil source diversification that would remove her from the risk of depending on the volatile Middle East and ensure the war against terrorism and good governance is embraced by her partners,--- china, EU and Africa. This argument holds that it is also to the interest of all partners, where security to the international community and oil extraction is concerned, since it is the common resource that benefits all

Marks and Evans (2007) cite five points to guide in this approach in which there is mutual interference among china-U.S and Africa, with the first two becoming increasingly dependent o African oil imports and Africa relying on the revenues. For the industries to be well managed for benefits to all, these initiatives have to be followed:

(a) Ensuring security of supply is very critical.

(b) Ensuring that generated revenues go into provision of development in extracting communities through job creation and provision of infrastructure.

(c) Promoting the idea of international extractive industries transparency initiatives (TEITI), this promotes transparency in the dealings of revenues and encouraging oil companies to publish what they pay to governments.

(d) Deeping corporate, social responsibility efforts of multinational companies to commit US\$1 million for every 100,000 barrels of oil for projects in the communities and investments in microfinance to resettle combatants and to avoid the "Dutch disease" syndrome, governments should understand the implication of oil boom and address the inherent issues of diversification and investments to cushion its effects.

All parties should understand that good governance, transparency, responsible, infrastructure and human development are essential to development, security and sustainability of oil exports. An aggressive pursuance of these initiatives would provide the needed benefits of cooperation. Good governance remains essential in generating the needed productivity for attainment of MDGS and link governmental institutions and civil society in an effort to promote economic development and social progress; through freedom and participation of citizens. And since corruption which plagues the continent is estimated at $\$ 150$ billion annually and like a crime imposes significant taxes on development and impedes economic growth, the partnership should enshrine measures to it.

\section{Conclusion}

Economic integration remains the most contentious element of globalization, yet it is the most option for rapid economic growth that permits free flow of goods and services, ideas and technology that fuels economic growth which benefits both developed and developing nations. The costs and benefits of open markets that helps to restrain consumer process and offset inflation which disrupts growth, depends on the ability of a nation to effectively interact with other nations. For Africa that is witnessing current volume of trade would require harmonized efforts of china, EU and the US as its major trade partners and donors in consultation with African union using NEPAD agenda, national and regional agencies, investment flows, improved infrastructure and trade liberalization in agriculture that can profoundly altar its economic growth and prosperity.

Equally, significant is the fact that using this model of partnership through shared values, technology, research and expertise in agriculture along with open trade which is noted as one of the strongest forces that stimulate economic growth, would dramatically increase food production from existing land without putting pressure on the soils and other natural resources. Since it is anticipated that variability in climate change would 
The International Monetary Fund (Imf) And World Bank: An Assessment Of The Role Of ....

affect livelihoods and where there are limited choices, could adversely affects crops yields, threaten famine and cause migration across borders, experts perceive it would significantly affect development in both developed and developing countries, therefore a concerted effort through this partnership would stem the damage.

\section{References}

[1]. Amenga-Etego, R. (2002) What Privatization in Ghana: An Analysis of Government and World Bank Policies.

[2]. Bello, W. et al (1993) "IMF/World Bank: Devastation by Design; Covert Action Quarterly

[3]. Feinberg, R. et al (eds)(1986) Between Two Worlds: The World Bank's Next Decade, New Brunswick, NJ, Transaction Books.

[4]. George, S (1988) A Fate Worse Than Debt, London,Pengiun.

[5]. Gwyn, R (1997) "IMF now Defacto Government for Millions", Toronto Star, December.

[6]. Halifax Initiative (1997) What is the G8 Hayter, T \& Watson, C. (1985) Aid: Rhetoric and Reality, London, Pluto Press.

[7]. Ismi, A. (1998) "Plunder with a Human Face: The World Bank, Z Magazine, February

[8]. Kofi, A. (1997) Ghana-World Bank: Star Pupil Has Second Thought on Reform

[9]. Lynas, M. (2000) "Letter to Zambia", The Nation, February, 14

[10]. Mining Watch Canada (2001) Reality- The Globalization of Natural Resources: Mining and the World Bank/IMF: A Special Focus on Ghana.

[11]. Naiman, R. \& Watkins, N (1999) “A Survey of IMF Structural Adjustment in Africa: Growth, Spending And Debt Relief”, Center for Economic and Policy Research.

[12]. Raymond, J (1991) "IMF medicine is killing those it Aims to save", The Globe and Mail, February

[13]. Sanders, B. (1998) "The International Monetary Fund is Hurting you", Z Magazine, July/August

[14]. SAPRIN (2002) The policy Roots of Economic Crisis and Poverty: A Multi-Country ParticipatoryAssessment of Structural Adjustment.

[15]. Schrieberg, D (1997) “Dateline Latin America: The Growing Fury”, Foreign Policy, Spring UN

[16]. (1999)) Economic Report on Africa

[17]. UNDP (2001) Human Development Report Weisbrot, M.(2000) “THE Emperor Has no Growth: Declining Economic Growth Rates in the Era of Globalization, CEPR.

[18]. World Bank (2001) World Development Indicators, Washington DC

[19]. World Bank (2002) "Making Monterrey Work for Africa: New Study highlights dwindling aid flows, Mounting challenges, Press Release, April 10 